\title{
Overview of Levee Setback Projects and
}

US Army Corps of Engineers $_{\circledast}$

\section{Benefits}

\section{by Travis A. Dahl, Charles H. Theiling, and Waleska Echevarria}

PURPOSE: This Coastal and Hydraulics Engineering Technical Note (CHETN) provides an overview of levee setback projects and their potential benefits. Levee setbacks relocate a traditional river levee farther away from the channel to provide additional floodplain storage, thereby reducing flood heights, slowing flood peaks, and in some cases, providing ecosystem and recreational benefits.

INTRODUCTION: Levee setbacks are generally defined in relation to existing, traditional levees. Typical levees constrain the overbank flow of a river to a defined channel to restrict the area of potential flooding. Levee setbacks relocate the levee farther away from the river channel to provide additional floodplain storage, reducing flood heights. This area between the levees and the main river is sometimes referred to as the batture. Figure 1 illustrates how a levee setback can be used to create additional floodplain and allow more room for the river to adjust.

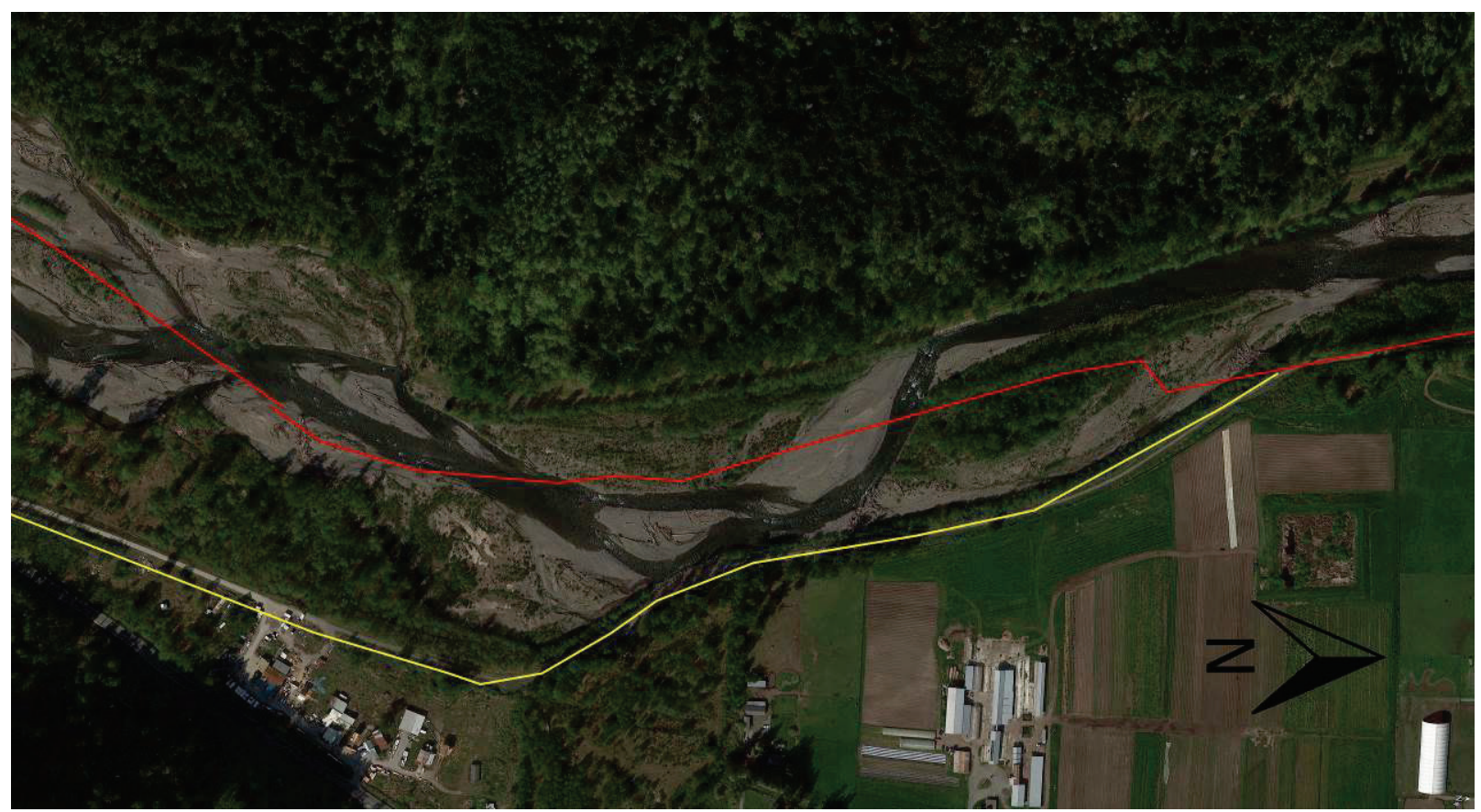

Figure 1. Levee setback on the Puyallup River in Washington State with flow from left to right. The red line indicates the historical right-descending bank levee alignment. The yellow line approximates the present setback levee, which has more than doubled the room for the river in some areas. 
Levee setback projects do not necessarily remove or relocate an entire levee (USACE 2012). Levee alterations that create "managed" or "staged" inundation may also be used to achieve the same objectives as levee setbacks. Additionally, typically during emergency flood fighting efforts, temporary levees may be deployed at prescribed places and river stages to manage the extents of flooding.

Alterations to levees that set portions farther back from the river or allow for staged inundations can be considered nonstructural flood risk management (FRM) techniques since they reduce the existing impacts of the levee structures on the natural river and floodplain processes. A more detailed discussion of this justification can be found in Smith et al. (2017).

The main driver of levee setbacks throughout much of the United States is flood risk management. However, in some places, such as the Pacific Northwest, the levee setbacks are primarily being built to improve habitat for ecosystem restoration. The city of Orting, WA, for example, attributes significantly reduced flood damages in 2006 to the Old Soldier's Home levee setback on the Puyallup River that was built primarily to allow the river to behave more naturally and improve salmon habitat ${ }^{1}$.

POTENTIAL BENEFITS: Levee setbacks can potentially improve the hydrologic aspects of an FRM project as well as the levee system resiliency by reducing the risk of failure. The reconnection of the river to a larger floodplain helps to reduce flow velocities, particularly during large flood events (USACE 2012; Opperman et al. 2010; Gergel et al. 2002). Levee setbacks can also provide additional space to account for potential climate variations and future economic expenditures related to that variability ( $\mathrm{hhu}$ et al. 2007). Additionally, private land acquisition (relocation of properties) can be considered as a way to lower risk and prevent future damage from flooding (Galloway 2005).

The most significant potential benefits of levee setbacks can be categorized as either flood damage/risk reduction or environmental improvement. For individual projects, there may also be additional economic and societal benefits.

\section{Flood Risk Management Benefits}

Setting a levee back farther from the river channel can reduce the potential flood peak in the area of the project by providing more space for the flood waters to spread out (Figure 2), thereby inundating a larger floodplain than would have occurred with a traditional, restricted levee system. This reduced flood peak will, in turn, reduce flow velocities and decrease the potential for scour and erosion, especially along the toe of the setback levee. Reduced flood heights will also result in reduced hydraulic loadings of the levee. As a result of lower flow velocities due to levee setbacks, scour and erosion will likely decrease. Because levee breaches are often caused by erosion and other factors, including overtopping and levee saturation, reductions in the scour and erosion potential can significantly increase levee safety. In cases where the setback levee is constructed with the same elevation as the original, a greater reduction in the risk of flood damage will result (USACE 2012). Such an action could help existing FRM projects adapt to changes in climate and hydrology with minimal loss of their intended purpose.

\footnotetext{
${ }^{1}$ Randy Brake, Pierce County Surface Water Management, personal communication, 5 April 2016.
} 



Figure 2. Resulting inundation and water surface elevations from a hypothetical levee setback. The top left panel shows the traditional levee configuration and velocities. The top right panel shows the effect of adding a large levee setback. The bottom panel shows the resulting hydrographs for both scenarios.

Generally, a levee setback will provide the opportunity for improved system level resiliency and reduce the risk of failure well away from its direct area of influence. In addition to the hydraulic effects at the setback location that were mentioned previously, the setback has the potential to decrease flow velocities and resulting hydraulic loadings across large portions of the system by reducing and retarding the peak flow. The strategic demolition of the levee protecting the Bird's 
Point-New Madrid Floodway is a stunning example of the rapid reduction in peak stages that can occur (Mississippi River Commission 2011).

The cost of constructing a levee setback may be lower than using a more traditional alignment because it may be possible to place the levee on a more stable foundation farther from the main river channel, and a reduced levee height will typically provide the same level of flood risk reduction (USACE 2012). Levee setbacks can also result in reduced Operation and Maintenance costs, as well as decreased repair, rehabilitation, and replacement expenditures (Smith et al. 2017).

Urban areas require greater flood risk reduction and may have existing infrastructure that limits levee setback opportunities in some locations, making remaining FRM options relatively more critical. In a few instances, urban areas are protected by temporary flood barriers designed into parks and transportation networks. Some cities install cost-efficient temporary flood barriers, like Hesco Barriers, in convenient flood-fighting locations (Figure 3).

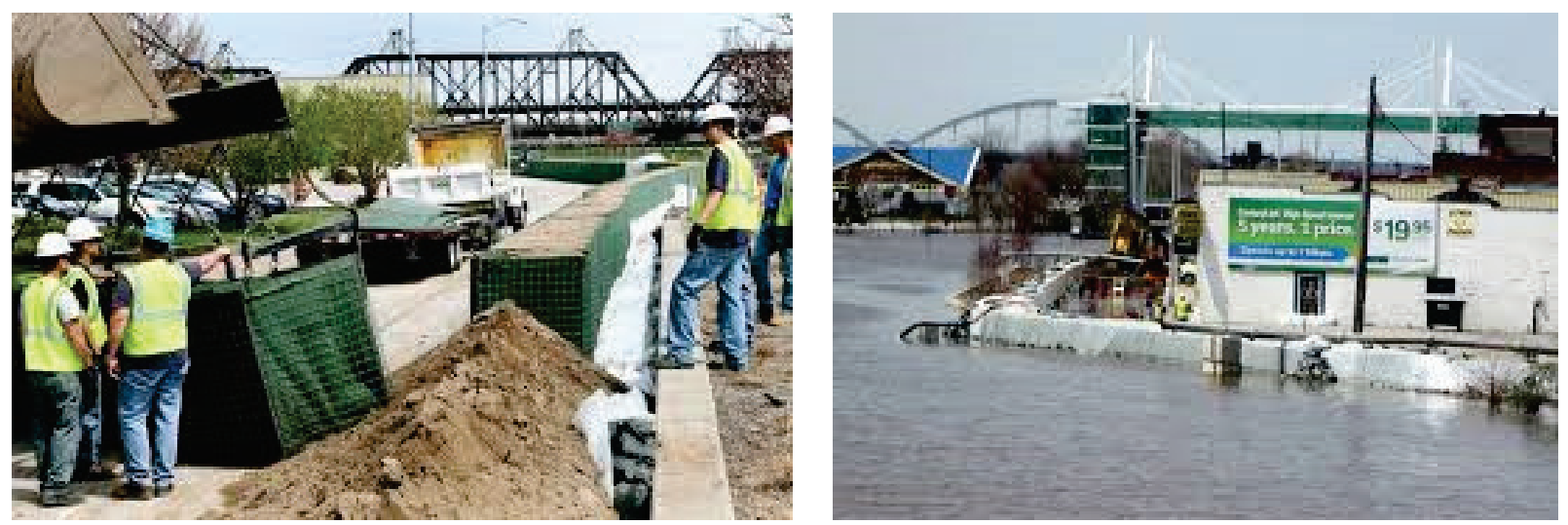

Figure 3. Temporary setback levee constructed of Hesco Barriers along Front Street in Davenport, IA.

\section{Environmental Benefits}

The environmental benefits of levee setbacks can be generally classified into the following categories: geomorphology, hydrology, biogeochemistry, habitat, and biota.

\section{Geomorphology}

Levees restrict geomorphic adjustments to a portion of the natural floodplain. They decrease floodplain capacity for most flows to reduce the risk of flood damages. The physical landscape setting (e.g., climate, watershed dimensions, valley width, riverbed slope, geology, prior disturbance) determines the form and structure of rivers. Each levee system is unique, based on the particular details of its setting. Common floods are confined up to the levee height, but extreme events can exceed design capacity.

Traditional levee placements reduce floodplain area and the time of travel for floodwaters, as well as the time available for chemical transformation of nutrients and other materials transported by the river. Geomorphic responses in the remaining connected floodplains (i.e., floodway or batture) can include increased sedimentation, topographic homogenization, and 
lower soil diversity. Sedimentation in the floodplain can significantly reduce the effectiveness of flood control projects, especially when coupled with increased upland erosion and hydrologic alteration in the watershed.

Aquatic habitats in connected floodplains are also subject to altered sediment transport, which influences habitat quality. Backwater lakes represent the deeper areas of floodplains and are prone to sediment deposition and infilling, with sediment accumulating in deeper areas first. The net result is loss of depth and degraded sediment quality in backwater lakes. Fine sediment can be easily resuspended by wind and waves in shallow impounded backwaters, which reduces light for aquatic plants.

Former floodplain areas, isolated behind levees, are affected by the lack of connectivity and sources of sediment. Consolidation of soils behind levees due to internal drainage without incoming replacement sediment increases ponding, associated pumping costs, and flood damage during extreme events. Floodplains behind levees do, however, retain some of the historic topographic diversity buried by post-settlement alluvium in the connected floodplain. Isolated backwater lakes in levee districts may be protected from excessive sedimentation and retain high quality habitat, but even infrequent overtopping can introduce sediment and disturb managed fisheries with riverine species, including aquatic nuisance species.

Levee setbacks can restore sediment transport dynamics in re-connected floodplains. Geomorphic structures like bypass channels, dikes, barbs, and hard points can be created to simulate and enhance natural processes. Floodplains cut off by levees can be enhanced by moving sediment from setback areas into the crop fields, where it can raise elevations, enrich soil, or enhance levee performance. Floodplain Lowering is a viable management practice used with precision in urban watersheds and also in the Netherlands on a river-reach scale.

Off-season flooding of agricultural levee districts from tributaries or mainstem rivers may provide many soil benefits that improve crop productivity while also providing ecological benefits such as shorebird migratory habitat (Twedt et al. 1998). This management practice is used in many areas and has significant potential to expand its application to other leveed rivers.

\section{Hydrology}

As discussed previously, traditional levee placements restrict floodplain flows to confined areas near the river channel. This constriction of flow alters the natural hydrologic attributes, including magnitude, timing, duration, and frequency of events like floods and droughts. Levees can reduce the risk of flooding in specific areas, but they also impose hydrologic and hydraulic impacts in the floodplain outside of the leveed area. River stage-discharge relationships are altered such that flows spread over less area and stages rise higher in levee-constrained reaches. Levees thus increase the magnitude of common floods within the floodplain, so native plant and animal communities are directly affected by more frequent flooding. The timing and duration of hydrologic events are changed by complete loss of flooding in leveed areas. Floods may also be shorter and more severe, rising and falling quickly as they move rapidly through managed floodplains. Such rapid flooding may not allow sufficient time for spawning or other life-history stages of fish and other aquatic organisms. Levees can also increase the frequency of common floods in the floodplain where they compress small floods to higher levels. Seasonal timing of 
floods may change since smaller rain events in drier seasons may rise to flood stage in confined floodplains. For similar reasons, the rate of change of flood levels is greater with levees because floodwaters rise and fall faster and higher in the confined space.

Levee setbacks can improve hydrologic conditions by providing more space for floodwaters to spread. There are direct ecological benefits like improved animal migrations and nutrient and sediment transport, but there are also more subtle effects. Hydrologic response is site specific, but improvements to natural flow attributes may be exhibited long distances from an individual levee setback project. Where gauges are lacking, hydrologic models can estimate the response to a levee setback over many river miles.

\section{Biogeochemistry}

Floodplain nutrient dynamics are complex, but there are some heuristics of transport and transformation that operate across most sites. Site-specific responses, however, can be quite complicated and difficult to quantify without accurate flood inundation estimates. In general, floodplains are nutrient sinks that accumulate or mineralize material in alluvial areas. Low connectivity between the river and floodplain during floods eliminates a local nutrient sink, contributing to higher nutrient loading downstream.

Low floodplain connectivity (i.e., a limited ability for water to move between the river and the floodplain) reduces water residence time, which is important for physical and biological responses to occur. Denitrification achieved by algae in the water column will be higher where surface water residence times are greater. Flooded terrestrial vegetation can also provide substrate for microbial biofilm that boosts denitrification further. Phosphorus will behave differently than nitrogen because it is often bound to clay particles and travels with fine sediment. Phosphorus may settle in terrestrial floodplains where it becomes available to plants, or it may end up in backwater lakes that can become phosphorus enriched and eutrophic. Carbon dynamics are also complex, but carbon can be transformed and stored in many biological pathways where it may ultimately be sequestered.

Levee setbacks mitigate many biogeochemical impacts of traditional levees by increasing hydraulic connectivity. The extent of benefits is determined by the extent a setback restores hydraulic connectivity, which can be estimated with hydraulic modeling tools used to design levees. Contemporary levee design projects often have accurate hydraulic modeling tools to estimate such benefits.

\section{Habitat}

Levees themselves occupy a relatively small spatial footprint that displaces native vegetation. The leveed area, however, may already have experienced land conversion to crops or structures that caused a direct effect on habitat and created the need for flood protection. The larger spatial area affected by levees is due to the hydrologic and hydraulic impacts. The areas behind levees are typically developed urban areas or in use for agriculture, but there is often substantial drainage that also reduces interior wetland abundance. Thus the hydrologic impact, and habitat value, in the leveed area is typically much drier and more heavily managed than it was prior to development. Hydrology, in the main channel and batture areas, is accentuated by levees 
compressing the floodable area. Impacts on flood heights and natural hydrology in connected habitats will negatively impact the less flood-tolerant species exposed to more extreme events. Changes in floodplain vegetation will, in turn, affect habitat for other species.

Levee setbacks can restore hydrology rather quickly once the river and floodplain are reconnected whereas plant and animal communities respond more slowly. Plant communities may be planted as part of an overall ecosystem restoration focused on restoring native species and processes.

\section{Biota}

Levees impact biota by blocking access to floodplain habitat, hydraulic refugia, and by changing the hydrologic environment in the remaining connected floodplains. The direct effect of impeding access to floodplains is a reduction in the availability of migratory, feeding, reproduction, and overwintering habitat for backwater and floodplain fishes. Small fishes will have less refuge from flood flows and will expend more energy on survival than growth. Birds may overcome levee impacts because of their high mobility, but low-mobility species can be severely impacted. Native plants, for instance, were likely replaced by crops, but they may be able to grow under the hydrologic conditions created by a levee setback (Hine et al. 2016) if they are reintroduced intentionally or by natural dispersal mechanisms. Changes in soil characteristics and elevation relative to river stage can also have significant effects on plant communities. Restrictions in floodplain width typically create more severe conditions for less mobile species whereas broad floodplains, with lower stages and velocities, can provide good habitat for these species.

Levee setbacks can relieve most of the hydraulic stressors affecting aquatic habitats by spreading river flow over a greater area, but it is important to consider the relative tradeoffs among competing uses and costs for changing existing land uses. For example, further restoration may be required on newly acquired croplands to provide high quality habitat.

\section{Other Benefits}

An additional benefit that may be attributed to some levee setback projects is the use of floodborne sediments to supplement fertilizers in flooded farm fields. Historically, floodwaters were a significant source of nutrients in many major agricultural regions, such as the Nile River valley.

Some levee setback projects are designed as multi-use projects by placing recreational areas in the enlarged batture area. These areas may consist of playgrounds, soccer fields, or simply nature trails and can become a focal point for community activities.

CHALLENGES: There are a number of potential obstacles to levee setback projects. Presently, many potential levee setback projects are not considered to have a sufficient benefit-cost ratio because the land is expensive and large areas are affected by these projects. In urban areas levee setbacks may target repetitive flooding though costly buy-outs, relocation, and re-zoning. In agricultural areas, trade-offs contrast environmental and FRM benefits against costs of easements and loss of crop production. In some cases, costs can be justified by including the additional benefits of the levee setbacks, such as ecosystem goods and services. However, it should be noted that if ecosystem restoration is used to justify the levee setback, any incidental flood risk 
reduction "must be cost effective and incrementally justified," based on current U.S. Army Corps of Engineers (USACE) policy (Darcy 2016).

Public perception may be a limiting factor for proposed levee setbacks, and it is critical to engage all stakeholders early in the planning process. Projects are more likely to be successful if landowners are enthusiastic participants who can see the potential benefits for both themselves and their community. Urban communities may be supportive if provisions are made for public access and use of the levee setback areas. Agricultural landowners may be supportive of measures where they retain land ownership through easements and get reduced insurance premiums and reimbursement for crop damages from intentional flooding.

There are a number of policy considerations, such as potential impacts to FEMA flood zones and impacts to the local tax base. Smith et al. (2017) provide a good overview of many of the USACE policies that should be considered.

Thought must also be given to the technical considerations of designing a levee setback. Hydraulic models will need to be developed, and it may be necessary to include two-dimensional flow and sediment in the model to fully understand the effects of the setback. Decisions will need to be made about whether the river channel will be allowed to evolve within the expanded leveed footprint or if it will be locked in place through bank stabilization techniques. Also note that regional differences in geology, topography, and climate will significantly influence the success of a setback design.

SUMMARY: Levee setbacks have the potential to reduce flood risk while also improving ecosystem services and providing additional benefits. To achieve these goals, setbacks need to be carefully planned with both the support of local stakeholders and a multi-disciplinary team of technical experts. When properly planned and executed, levee setbacks are a valuable addition to the flood risk management toolbox.

ADDITIONAL INFORMATION: This Technical Note was prepared by Travis A. Dahl and Waleska Echevarria, research hydraulic engineers at the Coastal and Hydraulics Laboratory (CHL), U.S. Army Engineer Research and Development Center (ERDC), and Charles Theiling, Mississippi Valley Division Regional Technical Specialist. Questions about this CHETN can be addressed to Mr. Dahl (601-634-2371; Travis.A.Dahl@usace.army.mil.).

This Technical Note should be cited as follows:

Dahl, T. A., C. H. Theiling, and W. Echevarria. 2017. Overview of levee setback projects and benefits. ERDC/CHL CHETN-VII-17. Vicksburg, MS: U.S. Army Engineer Research and Development Center. http://dx.doi.org/10.21079/11681/ $\underline{22767 .}$.

\section{REFERENCES}

Darcy, J. E., Assistant Secretary of the Army. 2016. Puget Sound Nearshore Ecosystem Restoration Project (PSNERP) Nooksack River Delta Setback Levee - Policy Concurrence. Memorandum for Deputy Commanding General for Civil and Emergency Operations. Washington, DC, May 26, 2016. 
Galloway, G. E., Jr. 2005. Corps of Engineers Responses to the Changing National Approach to Floodplain Management since the 1993 Midwest Flood. Journal of Contemporary Water Research \& Education 130(1):5-12.

Gergel, S. E., M. D. Dixon, and M. G. Turner. 2002. Consequences of Human-Altered Floods: Levees, Floods, and Floodplain forests along the Wisconsin River. Ecological Application 12(6):1755-1770.

Hine, C. S., H. M. Hagy, M. M. Horath, A. P. Yetter, R. V. Smith, and J. D. Stafford. 2016. Response of Aquatic Vegetation Communities and Other Wetland Cover Types to Floodplain Restoration at Emiquon Preserve. Hydrobiologia. doi 10.1007/s10750-016-2893-5.

Mississippi River Commission. 2011. 2011 MR\&T Flood Report: Mississippi River Commission. http://www.mvd.usace.army.mil/Portals/52/docs/MRC/MRC_2011_Flood_Report.pdf.

Opperman, J. J., R. Luster, B. A. McKenney, M. Roberts, and A. W. Meadows. 2010. Ecologically Functional Floodplains: Connectivity, Flow Regime, and Scale. Journal of the American Water Resources Association (JAWRA) 46(2):211-226.

Smith, D. L., S. P. Miner, C. H. Theiling, R. Behm, and J. M. Nestler. 2017. Setback Levees: An Innovative, CostEffective, and Sustainable Solution for Improved Flood Management. ERDC/EL SR-17-3. Vicksburg, MS: U.S. Army Engineer Research and Development Center.

Twedt, D. J., C. O. Nelms, V. E. Rettig, and R Aycock. 1998. Shorebird Use of Managed Wetlands in the Mississippi Alluvial Valley. American Midland Naturalist 140:140-152.

U.S. Army Corps of Engineers (USACE). 2012. Assessment of Conceptual Nonstructural Alternative Levee Setbacks along the Missouri River. (Lower L-575 / Upper L-550 and Lower L-550) Final Report https://protectthemissouri.files.wordpress.com/2010/10/conceptual levee setbacks final report-2.pdf

Zhu, T., J. R. Lund, M. W. Jenkins, G. F. Marques, and R. S. Ritzema. 2007. Climate Change, Urbanization, and Optimal Long-Term Floodplain Protection. Water Resources Research 43:W06421.

NOTE: The contents of this technical note are not to be used for advertising, publication, or promotional purposes. Citation of trade names does not constitute an official endorsement or approval of the use of such products. 